\title{
Conflict of Interersts in Scientific Study and Bioethics as Professionalism
}

\author{
${ }^{\dagger}$ Kyung-Hee Lee \\ Department of Ethics Education, Sungshin Women's University, Seoul 136-742, Republic of Korea
}

\begin{abstract}
Science in the 21st century does not consider participants' welfare, safety and human rights in clinical studies, but modern science puts economic profits in its priority. This leads to a growing concern about social responsibility and professionalism ethics of companies, sponsors and scientists. Specifically, there is no way to control conflicts of participants' welfare with economic profits, leading to simply relying on individual ethics, social responsibilities and audit. This paper helps relevant agencies and people involved understand conflict of interest. Also this study presents the guidelines as well as independence, autonomy, ethical imagination and phronesis required for scientists.
\end{abstract}

Key words : Conflict of interersts, Scientific study, Bioethics, Social responsibility, Professionalism, Deprofessionalism, Independence, Autonomy, Moral imagination, Phronesis

\section{INTRODUCTION}

In response to the question "Who has decisive right in scientific study?", the answers are "Pay the Piper (He who pays the piper calls the tune)", "Never bite the hand that feeds you", and "Revolving Door." This came from specialized scientists who concentrated on their research due to the support of royalty and nobles under the prosperity of modern science in the $18^{\text {th }}$ century. However, science in the $20^{\text {th }}$ century neglects participants' welfare, safety and human rights in clinical studies. Instead, modern science puts economic profits in its priority. This leads to a growing concern about social responsibility and professionalism ethics of companies, sponsors and scientists.

In addition, institutionalized system as well as education for preventing conflict of interests are urgently required as clinical experimental studies increase after Korea-America FTA in Korea. Clinical experiment market compared to
'Golden goose' is 14.3 trillion won in terms of the worldwide scale, and 500-1,000 billion won in terms of the domestic market scale, which reflects changes in paradigm of new medicine clinical test. This is because structural problems between America and Europe such as burden for high price, and development of new medicines based on marketability, causes the central axis of clinical test to change from existing America and Europe to emerging markets and the third world countries. Boer warns that drug companies outsource clinical test to CRO, puts more emphasis on efficiency rather than ethics, and take advantage of poor patients of the countries lacking in their management to take clinical tests on a large scale.

Belmont Report and Helsinki Declaration, and Article 11 (Composition and operation of institutionalized committee) of the Korean Bioethics and Safety Act simply refer to conflict of interests. However, there is no compulsive restrictive system to control such a conflict when economic

\footnotetext{
Manuscript received 22 November 2013, Received in revised form 13 December 2013, Accepted 24 December 2013

${ }^{\dagger}$ Corresponding Author : Kyung Hee Lee, Department of Ethics Education, Sungshin Women's University, Seoul 136-742, Republic of Korea. Tel. : +82-2-920-7629, Fax : +82-2-920-7226, E-mail : leekh64@sungshin.ac.kr

* IRB Committee(non-scientific) Member of Korea University Anam Hospital, AAHRPP Fellow

This is an Open Access article distributed under the terms of the Creative Commons Attribution Non-Commercial License(http://creativecommons. org/licenses/by-nc/3.0) which permits unrestricted non-commercial use, distribution, and reproduction in any medium, provided the original work is properly cited.
} 
interests and individual interests conflict with each other in scientific study. Especially, a special training is required to relevant agencies and manpower such as researchers involved in scientific study, persons in charge of policies, governmental and private institutions, IRB committee members, persons in charge of public administration, and CRO (Contract Research Organization). Investigators as specialists have a social responsibility to predict and prevent risks for conflict of interests between welfare of subject of clinical study and economic interests in clinical study. This paper aims to help investigators understand and solve problems related to conflict of interests which they will face in scientific study.

\section{CONFLICT OF INTERESTS}

\section{Meaning of conflict of interests}

The word of conflict of interests is usually used when a warning is given to the people holding position likely to win confidence from the public because they are exposed to risk that they may commit actual or potential misdeeds. It also means to take an action in order for moral indiscretion, misdeeds or violation of laws not to occur. Also, terms such as 'self-serving', 'corruption of relatives', 'misuse of power', 'misappropriation of public funds', 'insider trading', 'revenge', etc. are also used. Conflict of interests exists in any organization, and the more the organization becomes complicated, that is, the larger the number of relation involved, the higher the possibility of conflict of interests.

\section{Three steps in action of conflict of interests}

Andrew Stark proposes three steps in action of conflict of interests as follows in his book 『Conflict of Interest in Public Life』 (Stark, 2003).

Step 1 (antecedent act) : A step of having a person's mind lean by favor and so that the person can't practice the responsibility to put priority public profits over private profits.

Step 2 (state of mind) : A step of representing given behavior, deleted emotion, tendency, a liking, etc. through prior action. For example, it means emotion or tendency of pursuing for special profits unless other conditions are given.

Step 3 (outcome behavior) : A step in which action (decision making) is taken from the state of mine influenced from prior conditions. Such action is expressed through an act of giving benefits to one's relatives at the expense of public interests. At last, the prior action is to be expressed as biased acts through state of mind. The problems is that it is difficult to determine the prior behavior in respect of prior action and how the state of mind is. In conclusion, a method of conflict of interests is focused on 'Result' acts, so that a problem exists that preventive effects against Step 3 biased action can't be got.

\section{Economic conflict of interests and personal} conflict of interests

Tommy Thompson said that a situation in which scientists are fettered because of conflict of interests occurs when 'the first interests' - patients' welfare or feasibility of study, etc. — are likely to be influenced by the second interests such as financial income'. In a report of Association of American Medical College stated that such a situation is one of damaging or likely to damage specialized decision of researchers in a study report in consideration of financial or individual reason. That is, conflict of interests appears as economic or personal conflict.

First, economic conflict of interests shows when personal or economic interests of specialists and those of subjects, patients or customers conflict with each other. For example, if as 'action of situation' a researcher who compares and studies drug $\mathrm{A}$ and another drug $\mathrm{B}$ holds considerate amount of shares of A company, the researcher will prefer a conclusion that drug A excels drug B.

The matters requiring to pay attention and check in relation to economic conflict of interests are as follows. Following matters should be considered.

- Economic income when all the economic incomes of 
family members of someone, that is, his/her parents, spouse, persons living together in commonlaw marriage and children are summed; economic income in a case where he/she acquired shares of a sponsor exceeding an amount corresponding to ten million won or $5 \%$ of his/her all shares

- Compensation according to employment (other agency than research funds supporting agency)

- Monetary reward for consultation advice, etc.

- Ownership of shares or equity or option

- Intellectual property right (patent right, copyright, trademark right, use right or royalty contract)

- Monetary reward for expert statement

- Lecture fee to be paid to a lecturer and gifts and expenses for business trip

Second, personal conflict of interests appears when conflict related to competitive royalty toward two or more subjects, patients or customers occurs and sometimes when a third party conflict among a requester for study, an insurance company, an employee, etc. occurs in relation to contract with subjects, patients and customers. For example,

- In case an author who submitted an application for a study fee belongs to the same organization as an academic scientist

- In case such a scientist participates in an evaluator for such a study fee

There has been 'intellectual split toward science' in a scientific world, which sometimes causes the evaluation of quality of a thesis subject to evaluation between edition staff to go from one extreme to another. If someone is alone without any supporter is to be unfavorable when an opinion for or against a special theory is presented.

\section{Three issues in typical cases of conflict of interests}

It is possible to draw following issues from a case of female breast prostheses silicon outflow of John Moore Case (1976-1981), Jesse Gelsinger Case (1981-1999), the most typical case of conflict of interest in scientific study.

First, clinical researchers can exclusively posses the physical pieces or genetic information coming out of their patients as intellectual property right. Second, doctors underestimate risks of experimental measures in their clinical study owing to financial interests, so that they are likely to neglect protection of patients. Third, financial interest of researchers or sponsors can have an effect on a method of researcher studying or a method of interpreting study results.

\section{CONFLICT OF INTERESTS IN SCIENTIFIC STUDY AND RELEVANT ETHICAL PROBLEMS}

\section{Maintenance of scientific integrity}

More emphasis may be placed on commercial profits than progress of scientific knowledge for reason of economic relation between researchers and research institutions and companies. Sponsors may monopolize information, escaping from pursuit of competitive companies, and restrict publishing of study results, and avoid intentionally abnormal reaction or side effects being disclosed to the public. Partial or restrictive opening of study results is likely to increase expenses in the process of clinical test and to threaten to endanger the future study and patients. Also it may influence a study plan and performance such as treatment methods subject to test, for example, comparison of drugs or comparison experiment of other drugs, point of time of favorable or negative termination, standard of selection of exclusion of subjects, study change, etc. In paying research funds to a doctor in charge, if a medical institution pays excessive research funds to a certain doctor in charge, a relevant researcher or institution is more likely to select the study tasks of the medical institution which supports plenty of research funds than to select the study useful to patients or society.

\section{Protection of subjects}

Researchers shall be persons who can meet the demand 
and reliance of the general public. Especially, it is very unethical to receive a reward through exchange of medical information of patients. Therefore, following standards and laws of interest conflict is needed for managing, reducing and removing conflict of interests.

Researchers shall open economic profits that may be influenced by study results prior to his/her starting study. When interest conflict occurred, relevant researchers shall make a report to an institution and take an action for managing, reducing and removing interest conflict. The first strategy is disclosure and prevention, and as relieved access methods, there are peer review of a study plan, an independent supervision activity of study, trust in the name of a third party, prevention of intervention of researchers having interest conflict and disclosure of economic interest in a written approval.

\section{DEPROFESSIONALISM}

\section{Moral corruption of investigator}

It is needlessly to say that investigators are main power taking the lead in changing structure of Korean society as professionals. However, as the unavoidable competition between professionals becomes keen and great number of professionals appear, a phenomenon of moral degeneration is becoming severe. Danial Bell says that professionalism assuring social position of specialized job conflicts with populism asserting greater rights and participation in society (Bell, 1976). Considering that occupational influence and economic compensation are the most important elements which compose professional power, the power is remarkably being weakened.

\section{Damage of independence and autonomy of} professionalism

Professionalism is a series of value centering around autonomy and independence based on special job. Eliot Freidson defines professions as institutional environment in which members of professions themselves control labor and takes note as to a certain systematized occupation can obtain power able to control qualification of carrying out a series of prescribed duty, prevention of other's business execution, and standards for performance evaluation (Freidson, 2001).

But, Freidson points out that professions today gradually loses confidence from the general public, destroying their identity for themselves and depending on capital and the nation. The terms such as 'monopoly', 'social closure', 'credentialism', 'elitism' are the typical words used for a sharp criticism of professions. He stresses that the essence of professional labor exists in altruism and the public good which put priority on the public interests based on 'reliance' (Freidson, 2001). Suppose the very dignity and social position of professions can be obtained only when professionals can disregard economic self-interest. Therefore, the monopolistic position and autonomy in Professionalism should be obtained in the process of trying strict selfregulation and the public good not in the process of trying for maximum profits.

Damage in autonomy of professions has been accelerated as dependence upon technology is expanded in medical area (Postman, 1993). As the belief is widely expanded that the results and information obtained through machines have more value than individual decision and insight, the autonomy, the essential value of professions collapsed (Cockerham, 2011). Hans-Georg Gadamer points out that only technical aspects of modern medical science were stressed and the work of applying such knowledge bears so much responsibility that such work is not regarded as a widespread human and social occupation (Gadamer, 1987). This is an important passage allowing us to consider what the main duty of a doctor is in medical and practical area escaping from mechanical application of scientific technology.

\section{Investigators employed in a company}

Appearance of a huge global medical enterprise targeting on generation of profits and medical care - industry complex, etc. becomes main cause for accelerating deprofessionalism of professions. It seems natural for a doctor 
to lose clinical autonomy and specialized control in a medical company aiming at pursuing maximum economic profits. Excessive medical treatment, unnecessary examination, high-priced treatment become popular, and a doctor who neglects public duties in medical care loses the dignity as professions and, at the same time, shows a typical case of damaged professionalism. At last, a short-term viewpoint for the purpose of expanding economic profits leads to the decline of professions. I will try to propose the conclusion as citing Freidson.

"If there exist right and risk accompanied by specialized jobs, it is essential to establish agenda for academic development and to have freedom responsible for academic use.

Accordingly, the most important problem incidental to the future professionalism is not economical or structural problem but cultural and ideological. Needless to say, the most important problem is the spirit of professionalism (Freidson, 2001)

\section{'PHRONESIS' AND 'MORAL IMAGINATION' AS PROFESSIONAL ETHICS}

To maintain professionalism, a role is important as a moral manager of expert knowledge and technology not a simple expert (technician) having knowledge and technology (Polanyi, 1974). With regard to problems of knowledge and division necessary for professionals, Gadamer says that the words of medical care is separated from techne as simple manufacturing ability. Therefore, the knowledge of a doctor giving medical care is different from technician an engineer applies mechanically (Gadamer, 1987).

The more the mechanical aspects between theoretical knowledge and practical application are reinforced, the more autonomous judgment is to be restricted. This is the reason that not techne of mechanically acquiring and applying but judgment type requiring a continuous process of self-reflection and interpretation, that is, reasonable consideration and moral imagination are important to for doctors.

Judgment is 'the essence of interpretative experience' and character possessed by 'a wise person (phronimos)'. Such a type of person does not aim for completed knowledge, but aims for 'openness' of new experiences. Usually, phronesis called to as 'practical wisdom' is a useful concept in making the best decision in various situations under which definite and fixed answers can't be given. Phronesis is ability promote good life look into what the good and the bad are to a human being (Thomson et al., 2003). Accordingly, phronesis is not ability simply to select suitable means, but state of moral character established as moral existence. In conclusion, phronesis is ability to select and decide among various possibilities through all areas of our life, escaping from technique which can be obtained through simple learning (Gadamer, 1987). This is the ethical ability necessary for investigators as professionalism ethics.

\section{DISCUSSION}

It is required to give an education to relevant agencies and manpower such as researchers involved in scientific study, persons in charge of policies, governmental and private institutions, IRB committee members, persons in charge of public administration, CRO (Contract Research Organization), etc. Investigators as specialists have a social responsibility to predict and prevent risks for conflict of interests between welfare of subject of clinical study and economic interests in clinical study.

\section{ACKNOWLEDGEMENTS}

"This work was supported by the Sungshin Women's University Research Grant of 2013”.

\section{REFERENCES}

Airaksinen T (1998) Professional Ethics Encyclopedia of Applied Ethics vol. 3. 1st ed. Academic Press, San 
Diego, p 67.

Bell D (1976) The Coming of Post-Industrial Society: A Venture in Social Forecasting. 1st ed. Basic Books, New York, p 325.

Freidson E (2001) Professionalism: The Third Logic. 1st ed. University of Chicago Press, Chicago, pp 111-156.

Gadamer HG (1987) Theorie, Technik, Praxis. Gesammelte Werke 4 J.C.B. Mohr, Tübingen, pp 134, 167-231, 245.

Harris CE JR, Pritchard MS, Rabins MJ (2000) Engineering Ethics: Concepts and Cases. Wadsworth Inc., CA, pp. 12-13.

Krimsky S (2004) Science in the Private Interest: Has the Lure of Profits Corrupted Biomedical Research? 1st ed. Rowman \& Littlefield Publishers, Lanham, pp 201-278.

Michaels D (2007) Doubt is Their Product: How Industry's Assault on Science Threatens Your Health. 1st ed. Oxford University Press

Nelkin D (1995) Selling Science: How the Press Covers
Science and Technology. 2nd ed. W. H. Freeman \& Company, San Francisco, pp 110-164.

Polanyi M (1974) Personal Knowledge: Towards a PostCritical Philosophy. 1st ed. University Of Chicago Press, Chicago, p 457.

Postman N (1993) Technopoly: The Surrender of Culture to Technology. 1st ed. Ch 6. Vintage Publishing, London, pp 125-142.

Pritchard J (1998) “Codes of Ethics," Encyclopedia of Applied Ethics vol 1. 1st ed. San Diego Academic Press, San Diego, p 527.

Sheila J (1997) Science at the Bar: Law, Science, and Technology in America. 1st ed. Harvard University Press, Cambridge, p 47.

Stark A (2003) Conflict of Interest in Public Life. 1st ed. Harvard University Press, Cambridge, p 231.

Thomson JAK, Tredennick H, Barnes J (2003) The Nicomachean Ethics by Aristotle. Penguin Classics, London, pp 201-211. 